\title{
Book Review: The Sobibor Death Camp: History, Biographies, Remembrance
}

Norah Schneider

Salve Regina University

Follow this and additional works at: https://digitalcommons.usf.edu/gsp

\section{Recommended Citation}

Schneider, Norah (2018) "Book Review: The Sobibor Death Camp: History, Biographies, Remembrance," Genocide Studies and Prevention: An International Journal: Vol. 12: Iss. 1: 106-108.

DOI:

https://doi.org/10.5038/1911-9933.12.1.1557

Available at: https://digitalcommons.usf.edu/gsp/vol12/iss1/12

This Book Review is brought to you for free and open access by the Open Access Journals at Digital Commons @ University of South Florida. It has been accepted for inclusion in Genocide Studies and Prevention: An International Journal by an authorized editor of Digital Commons @ University of South Florida. For more information, please contact digitalcommons@usf.edu. 


\title{
Book Review: The Sobibor Death Camp: History, Biographies, Remembrance
}

\author{
Norah Schneider \\ Salve Regina University \\ Newport, Rhode Island, USA
}

The Sobibor Death Camp: History, Biographies, Remembrance

Chris Webb

Stuttgart, ibidem-Verlag, 2017

519 Pages; Price: $\$ 45.00$ Paperback

Reviewed by Norah Schneider

Salve Regina University, Newport, Rhode Island

Completing his trilogy on the Aktion Reinhardt camps (Belzec, Treblinka), Chris Webb provides a well-researched and profoundly needed text with Sobibor. ${ }^{1}$ Webb intended to, and succeeds, in presenting a history of the Sobibor death camp and remembering its victims. Providing extensive source references for those looking to continue their research into Sobibor, the book is divided into two parts. Part I, The Hell Called Sobibor, details the history of the camp beginning with the first planning of the camp in early 1942 and continuing through to its shutdown in November 1943. Part II, Survivors, Victims, Perpetrators, and the Aftermath, focuses on the people of Sobibor, both the victims and the perpetrators, as well as what happened to the perpetrators after the camp completed its role in the Holocaust. Webb also provides an appendix on the labor camps around the Sobibor death camp (Appendix 1) and an appendix on the Trawniki men who served at Sobibor (Appendix 2). Following the appendices, there are photos, documents, drawings, and maps offering a visual of what Webb discusses in his history. These are beneficial on their own as primary sources but also add extensively to the history Webb provides. The writing of Sobibor uses terminology that assumes the reader has a strong background not only in Holocaust and Nazi history but also in the German language. Recognizing this, Webb provides a chart of equivalent military ranks as well as a glossary of Nazi terms, but the writing could still be overwhelming for someone without any prior knowledge.

Chapter 1 provides a brief overview of Aktion Reinhardt, the plan to exterminate Polish Jewry in the Generalgouvernement in the Belzec, Treblinka, and Sobibor camps. Webb introduces the major players of the program and outlines how it, and therefore Sobibor, came about. He also discusses how Aktion Reinhardt ended and what happened to the officials involved after the war. Chapters 2 through 5 focus on the construction of the camp and the start and expansion of the exterminations. It is in these chapters that we see what makes Chris Webb's Sobibor so unique. It is the focus on the people. Webb's detailed history of the camp relies heavily on first-hand accounts from camp personnel as well as survivors. Part I is filled with large block quotes from Germans, Ukrainian guards, other eyewitnesses, and some rare survivors of the camp. Webb does note multiple times, however, that some of these first-hand testimonies do contradict each other and contradict other information available on the camp. It is clear that Webb desires to put as much information available into the text to deliver the strongest history of Sobibor he can. While it shows Webb's dedication to the victims of Sobibor to ensure the history of Sobibor is told, sometimes there is so much information provided, especially within the numerous long block quotes, that some of the details get lost as one tries to retain all of them while also remembering which person is recounting them.

Chapter 6 examines in depth the Jewish Work Brigades and provides some of the firsthand accounts of those Jewish prisoners chosen to live and work in Sobibor. Webb identifies the responsibility of each work kommando and uses a personal account to provide the details making it not just a general history but an intricate visual of their daily lives. Once again, Webb emphasizes his focus on the people as the essential part of the Sobibor history. This focus is truly the strongest

\footnotetext{
${ }^{1}$ Chris Webb, Belzec: The Death Camp Laboratory (H.E.A.R.T/Holocaust Historical Society, 2012); Chris Webb and Michal Chocolaty, The Treblinka Death Camp (Stuttgart: ibidem-Verlag, 2014). 
and most profound part of Webb's text. The Jewish prisoner eyewitness accounts continue in Chapter 7, joined by some SS accounts, with the recollection of Heinrich Himmler's visit to Sobibor in the winter of 1943. The later transports to Sobibor from other parts of Poland and Europe are also detailed by survivors in Chapter 8 , however, the lack of quotation marks around non-block quotes, an occurrence throughout the entire text but especially notable in this chapter, makes it difficult at first to distinguish primary accounts from Webb's own writing, thereby affecting the flow.

Chapters 9 through12 focus on the final months of the camp. Two major revolts happened at Sobibor in its closing months: the Waldkommando revolt on July 20, 1943 (Chapter 9) and the prisoner revolt on October 14, 1943 (Chapter 10). Webb presents these revolts through the eyes of the prisoners and the SS men. While the entire text is filled with incredible details of the camp and people's experiences there, the explicit descriptions of the October prisoner's revolt show why it ultimately led to the closing of Sobibor. Webb weaves each individual account together to form a complete picture of the events leading up to and the day's actual events. Chapter 11 picks up with the aftermath of the revolt, where Webb begins with SS men recalling their arrivals to Sobibor to assist. A most interesting part of these accounts is some men knew of Sobibor's existence prior to their arrival and some did not. While there are many outside of the Holocaust Studies field today that are not aware of Sobibor or may be aware of it but do not know much about it, at least in comparison to Auschwitz, Webb provides a wide variety of eyewitness descriptions to every aspect of the camp's existence to guarantee that everyone moving forward will have the chance to know of it. Chapter 12 completes the history of Sobibor discussing, as Webb calls it, the liquidation of the camp. A short chapter, it shows that the end of Sobibor is not the story, but instead all that leads up to it.

While it does not seem possible, given Webb's incredible attention to the individuals of Sobibor in the first section of the book, the second part of Sobibor focuses even more so on the people. This begins with Chapter 13 and the incredibly personal and meticulous roll of remembrance, placing a necessary spotlight on those lost forever at Sobibor as well as those who survived. Webb describes it as "an attempt to record some of the names of...those who set foot on the living hell that was Sobibor...to show these people were flesh and blood, and to honour their memory." ${ }^{2}$ It is not a complete list, as Webb points out not everyone is known, but for those where it is possible a brief biography is provided. ${ }^{3}$ The list is separated into sections, with some sections including those who survived Sobibor, those selected in Sobibor for forced labor in other camps, those deported from Germany to Sobibor, and victims of Sobibor from other European countries.

Throughout his history of Sobibor, Webb provided statements from survivors as well as the criminals responsible for these evils and in the second part of this book, he provides biographies on the perpetrators of Sobibor (Chapter 14). Webb describes "the Personnel who ran the camps and supervised the extermination activities as absolutely ordinary people." ${ }^{4}$ This chapter is especially helpful as one reads through the book and tries to keep track of everyone involved in Aktion Reinhardt and at Sobibor itself. In Chapter 15, he discusses the testimonies and trials related to Sobibor. This includes official records from the trials involving the Aktion Reinhardt camps, providing further details of the events at Sobibor as those involved recounted what they did. Webb again shows his insightful research and exceptional use of sources to provide a history of Sobibor through the people, both the innocent and the evil. In his Epilogue (Chapter 16), Webb provides more recent information on Sobibor, including his own eyewitness account of the camp from 2002. The Epilogue shows that the history of Sobibor continues, making Webb's work vitally important, more so as 2017 marks the 74th anniversary of the revolts at Sobibor and its closing.

Webb ends his Author's Introduction writing "the trilogy of books serves as a memorial to each individual who was murdered in these horrendous 'factories of death'." ${ }^{5} \mathrm{He}$ successfully honors them in Sobibor while also providing those in Holocaust Studies a detailed history of the

\footnotetext{
${ }^{2}$ Chris Webb, The Sobibor Death Camp: History, Biographies, Remembrance (Stuttgart: ibidem-Verlag, 2017), 156.

${ }^{3}$ Ibid.

${ }^{4}$ Ibid., 303.

${ }^{5}$ Ibid., 13.
} 
Sobibor death camp, the people lost, and the people responsible. In Sobibor, Chris Webb takes events in history and shows them not just as events on a timeline or events that are part of the larger atrocities known as the Holocaust or the Second World War but instead presents them as personal stories in people's individual lives that need to be learned and respected as such. 